\title{
PENGENDALIAN PERSEDIAAN MELALUI PENENTUAN PRODUK STRATEGI
}

\author{
Nurul Dzikrillah ${ }^{*}$, Humiras Hardi Purba, Dhonny Suwazan, Noer Wahjoedi \\ Program Studi Magister Teknik Industri, Fakultas Teknik, Universitas Mercubuana \\ Jl. Menteng Raya No.29 Jakarta Pusat
}

(Received: June, 112016 / Accepted: December 21, 2016)

\begin{abstract}
ABSTRAK
Fokus utama pada pemenuhuan kebutuhan pelanggan saat ini adalah pebaikan kualitas terus-menerus dan pengendalian biaya. Persediaan yang tersimpan dalam jumlah besar hanya akan berakhir sebagai pemborosan. Memilih kebijakan yang tepat dan mempertahankan optimalnya tingkat persediaan merupakan tanggungjawab personel PPIC dalam menjaga kestabilannya. Pemilihan kebijakan persediaan adalah sangat penting dalam menghadapi persaingan global yang intensif dan dinamis. Penelitian kali ini bertujuan untuk mengurangi nilai persediaan melalui penetapan strategi produk. Peneliti mengusulkan klasifikasi model persediaan berdasarkan perencanaan produksi dan demand pasar. Hasil yang didapat adalah nilai persediaan menurun tiap bulannya secara stabil dengan nilai persediaan untuk akhir tahun pada saat melakukan perhitungan inventory projection adalah sebesar 11.3 juta USD dimana mencapai target yang ditetapkan perusahaan yaitu sebesar 11.5 juta USD. Dan nilai DIO pada akhir tahun menjadi 75 hari.
\end{abstract}

Kata Kunci : persediaan; klasifikasi model persediaan; strategi produk; inventory projection

\begin{abstract}
Quality improvement and costs control are vital to organizations for work performance enhancement and fulfilling customers' requirement. Inventories that are stored in large amount of quantities will result in waste. It is a significant job for the inventory control personnel to select an appropriate policy and maintain an optimum level of inventory. The selection of inventory policy is very much important in the current scenario of intensive global competition and dynamic nature. The aim of this study is to reduce inventory value by determining strategy of each product. Inventory model classification was done based on production planning and total pending order. The result is inventory value reduce by the end of the year in 11.3 million USD which is achieve the target. The target was locked in 1.5 million USD. DIO value is 75 days by the end of the year.
\end{abstract}

Keyword: inventory; inventory model classification; product strategy; inventory proection

\section{Pendahuluan}

Pada era globalisasi ini, zaman sudah hiperkompetitif. Persaingan yang terjadi bukan sekedar "pertandingan" biasa, tetapi sudah mencapai pemberian nilai tambah pada produk dan jasa (Mutakim \& Hubeis, 2011). Nilai strategi-strategi untuk menghadapi berbagai tantangan bisnis sangat diperlukan. Pada saat ini mulai banyak bermunculan perusahaan-perusahaan baru dalam industri sejenis. Menurut data BPS pada berita resmi statistik yang dirilis pada Maret 2015, menyebutkan bahwa

\footnotetext{
${ }^{*}$ Penulis Korespondensi.

email: nuruldzikrillah@gmail.com
}

pertumbuhan produksi industri manufaktur besar dan sedang triwulan II tahun 2015 naik sebesar 5,44 persen (y-on-y) terhadap triwulan II tahun 2014. Kenaikan tersebut terutama disebabkan naiknya produksi industri barang logam, bukan mesin dan peralatannya, naik 16,43 persen, industri farmasi, industri kimia naik 13,13 persen dan jasa reparasi dan pemasangan mesin dan peralatan, naik 9,43 persen.

Perusahaan harus mampu memenuhi tuntutan pasar dengan mempertimbangkan kualitas dan efisiensi produksi. Salah satu unsur yang memerlukan adanya perencanaan dan pengendalian yang tepat adalah persediaan. Menurut Puspika (2013) persediaan merupakan modal kerja perusahaan yang paling aktif dan bernilai material. Pujawan (2005) 
mengatakan bahwa persediaan pada suatu bisnis adalah satu dari sekian banyak aspek yang bersifat tangible (nyata dan kasat mata) dari sekian banyak aspek yang dimiliki dalam menjalankan bisnis. Bahan baku, barang setengah jadi, dan barang jadi merupakan bentuk-bentuk dari persediaan yang setiap satuannya menggambarkan uang yang terikat sampai persediaan itu meninggalkan perusahaan sebagai barang yang terjual. Singkatnya, persediaan merefer pada stok atau apapun yang dbutuhkan dalam menjalankan bisnis. Stok ini mewakili satu bagian besar dari investasi dan harus diatur dan dikendalikan dengan baik untuk mendapatkan keuntungan yang maksimal. Barry, C. (2009) melengkapi pendapat Pujawan yaitu persediaan adalah aset terbesar dalam bisnis. Jika margin sebesar 50\%, maka berarti bahwa biaya dari produk adalah $50 \%$, yang artinya $50 \%$ dari penjualan bersih dihabiskan untuk pengendalian dan pengiriman.

Garai (2013) mengatakan bahwa persediaan yang tersimpan dalam jumlah yang banyak hanya berakhir menjadi waste dan penggunaan space yang cukup besar.

Dalam perusahaan industri yang cukup besar, personel supply chain harus mengupayakan metode yang lebih baik dalam mereduksi presediaan, mengatur kenaikan jumlah SKU (stock keeping unit), dan memenuhi keinginan pelanggan yang terus berkembang. Agar dapat berhasil, manajer persediaan telah menemukan bahwa persediaan klasifikasi sistem memberikan analisis penting dalam rangkaian supply chain dan inventory control. (Standford dan Martin, 2007).

Proses pengendalian persediaan dapat mengubah pengendalian persediaan dari kegiatan yang bersifat reaktif menjadi kegiatan yang bersifat proaktif yang memiliki dampak yang baik alam pengukuran performa bisnis (Dureno, D. J., 1995)

Penelitian ni dilakukan pada PT HI yang bergerak pada bidang industri kimia.

\section{Metode}

Memilih kebijakan yang tepat dan mempertahankan optimalnya tingkat persediaan merupakan tanggungjawab personel PPIC dalam menjaga kestabilannya. Pemilihan kebijakan persediaan adalah sangat penting dalam menghadapi persaingan global yang intensif dan bersifat dinamis (Gupta, et.al, 2012)

Penelitian dimulai dengan pengumpulan data yang dibutuhkan yaitu data sales forecast, production planning dan data pending order dalam jangka waktu tiga (3) tahun ke belakang. Kemudian data diolah dengan membuat rasio perbandingan antara production planning dan pending order. Ditambahkan juga dengan data DIO (days inventory out) sebagai indikator keberhasilan persediaan. Kemudian melakukan penentuan strategi produk untuk finish good dari hasil perhitungan rasio. Dalam beberapa tahun terakhir , kriteria teknik klasifikasi persediaan telah diperkenalkan . Terlepas dari harga dan penggunaan, kriteria lain seperti leadtime, biaya pemesanan , kelangkaan, daya tahan, substitusi , reparability, kesamaan, kekritisan dll telah dipertimbangkan. (Jamshidi, H., \& Jain, A. 2008). Kemudian berdasarkan pendapat diatas, kerangka berfikir diperluas untuk identifikasi yang lebih rinci antara model persediaan / sistem . Penulis mengusulkan klasifikasi model persediaan berdasarkan perencanaan produksi dan demand pasar.

Setelah didapat strategi produk, kemudian dapat menyusun yearly planning untuk finish good dan dapat dilakukan pemesanan kebutuhan raw material untuk satu tahun. Kemudian dilakukan perhitungan projection inventory untuk mengukur pengendalian persediaan. Setelah itu melakukan analisis dan kemudian didapat kesimpulan.

\section{Kajian Literatur}

Alfares (2007) menyajikan model persediaan untuk permintaan stok dependent demand, dimana biaya penyimpanan adalah fungsi dari waktu penyimpanan . Kwak et al . (2009) mengusulkan Vendor Managed Inventory (VMI) model merupakan model yang adaptif yang mengendalikan kuantitas pengisian tergantung pada perubahan permintaan pelanggan pada setiap periode, khususnya pada demand yang tidak stabil. Davood et al . (2012) mengusulkan sebuah model yang dapat mengklasifikasikan persediaan dan memilih kebijakan yang tepat untuk setiap kelompok produk untuk kinerja persediaan yang efektif .

\section{Persediaan}

Menurut Martani (2012, h.245) Persediaaan merupakan salah satu aset yang penting bagi suatu entitas baik bagi perusahaan ritel, manufaktur, jasa, maupun entitas lainnya. PSAK 14 (revisi 2008) mendefinisikan persediaan sebagai aset yang (i) tersedia untuk dijual dalam kegiatan usaha biasa; (ii) dalam proses produksi untuk penjualan tersebut; (iii) dalam bentuk bahan atau perlengkapan (supplies) untuk digunakan dalam proses produksi atau pemberian jasa.

Nasution \& Prasetyawan (2008) mendefinisikan persediaan sebagai sumber daya yang menganggur yang menunggu proses lebih lanjut. Yang disebut proses lebih lanjut tersebut adalah berupa kegiatan produksi pada sistem manufaktur atau kegiatan pemasaran.

Menurut Harjanto (2008, h.237) Sistem pengendalian persediaan dapat didefinisikan sebagai serangkaian kebijakan pengendalian untuk menentukan tingkat persediaan yang harus dijaga, kapan pemesanan untuk menambah persediaan harus dilakukan dan berapa pesanan yang harus diadakan.

Menurut Rangkuti (2007, h.14) Jenis-jenis persediaan pada perusahaan manufaktur yaitu: persediaan bahan baku, persediaan bahan pembantu pembntu atau penolong, persediaan barang dalam 
/proses, dan persediaan barang jadi (siap untuk dijual).

Menurut Kieso, et al (2009, h.412) Biaya yang dimasukkan dalam persediaan adalah Biaya Produk, Biaya Periode, dan Perlakuan atas diskon pembelian.

\section{Peramalan}

Menurut Murahartawaty (2009), peramalan (forecasting) merupakan bagian vital bagi setiap organisasi bisnis dan untuk setiap pengambilan keputusan manajemen yang sangat signifikan. Peramalan menjadi dasar bagi perencanaan jangka panjang perusahaan.

Menurut Hasibuan (2011), metode peramalan adalah suatu cara memperkirakan atau mengestimasi secara kuantitatif maupun kualitatif apa yang terjadi pada masa depan berdasarkan data yang relevan pada masa lalu.

Organisasi selalu menentukan sasaran dan tujuan, berusaha menduga faktor-faktor lingkungan, lalu memilih tindakan yang diharapkan akan menghasilkan pencapaian sasaran dan tujuan tersebut. Kebutuhan akan peramalan meningkat sejalan dengan usaha manajemen untuk mengurangi ketergantungannya pada halhal yang belum pasti. Peramalan menjadi lebih ilmiah sifatnya dalam menghadapi lingkungan manajemen. Karena setiap organisasi berkaitan satu sama lain, baik buruknya ramalan dapat mempengaruhi seluruh bagian organisasi. (Makridakis, 1988)

\section{Strategi Produk}

Make To Stock : Adalah tipe industri yang membuat produk akhir untuk disimpan. Kebutuhan konsumen diambil dari persediaan di gudang. Ciriciri Make to Stock : Standard Item, high volume, Terus menerus dibuat, lalu disimpan, Harga wajar, Pengiriman dapat dilakukan segera, customer tidak mau menunggu, Perlu adanya safety stock untuk mengatasi fluktuasi

Make To Order : Adalah tipe industri yang membuat produk hanya untuk memenuhi pesanan. Ciri-ciri Make to Order : Inputnya bahan baku, Biasanya untuk supply item dengan banyak jenis, Harganya cukup mahal, Lead time ditetapkan oleh konsumen/pesaing, Perlu keahlian khusus, Komponen bisa dibeli untuk persediaan

Assemble To Order: Adalah tipe industri yangg membuat produk dengan cara assembling hanya untuk memenuhi pesanan. Ciri-ciri Assemble to Order : Inputnya komponen, Untuk suppy item dengan banyak jenis, Harganya cukup mahal, Lead time ditetapkan oleg konsumen

Engineer To Order: Adalah tipe industri yang membuat produk untuk memenuhi pesanan khusus dimulai dari perancangan produksi sampai pengiriman produk. Ciri-ciri Engineer to Order : Produk sangat spesifik, Lead time panjnag, Harganya mahal (Pujawan, 2005)

\section{Hasil Dan Diskusi}

Perhitungan Days of Inventory Outstanding (DIO) atau hari edar persediaan, menunjukkan periode pemrosesan penjualan persediaan perusahaan. Periode pemrosesan yang terlalu tinggi dapat berarti bahwa terlalu banyak modal perusahaan yang terikat di dalam persediaan dan bisa menyebabkan barang-barang persediaan mengalami penurunan nilai harganya. Disamping itu, periode yang terlalu rendah juga bisa mengindikasikan bahwa perusahaan kekurangan dalam persediaan sehingga bisa berefek ke penurunan penjualan. Jika terdapat dua perusahaan memiliki kinerja yang sama, tetapi salah satunya memiliki perputaran persediaan lebih cepat daripada yang lain, maka dapat dikatakan bahwa perusahaan tersebut berprospek untuk tumbuh relatif lebih cepat.

Berikut dapat dilihat tabel perhitungan DIO tahun 2014 sampai 2016 (perhitungan tahun 2016 sampai bulan Maret, saat penelitan ini dimulai) untuk PT HI :

Tabel 1. DIO PT. HI $2014-2016$

\begin{tabular}{cc}
\hline Tahun & Nilai DIO \\
\hline 2014 & 206 \\
\hline 2015 & 130 \\
\hline 2016 & 121 \\
\hline
\end{tabular}

Perhitungan nilai DIO didapat dari jumlah nilai uang dalam 1 bulan dibagi dengan jumlah penjualan (dalam satuan mata uang) dikalikan dengan 30 (estimasi 1 bulan dianggap 30 hari). Berdasarkan pengumpulan data masa lalu, didapat nilai DIO untuk tahun 2014 dan tahun 2015. Untuk tahun 2016 menggunakan DIO sampai bulan maret, dimana pada saat penelitian ini baru berlangsung. Dari data tersebut dapat dilihat memang mengalami trend penurunan. Namun nilai ini masih dianggap masih kurang baik karena masih memiliki gap yang sangat jauh dari target, yaitu 90 hari. Nilai 90 hari ini ditetapkan oleh perusahaan melalui diskusi yang panjang dari tingkat commercial, regional dan site.

Untuk dapat menentukan strategi produk, pertama-tama yang dilakukan adalah menentukan rasio perbandingan antara total demand (jumlah order) dan total supply (jumlah produksi). Penentuan strategi ini juga mempertimbangkan production wheel (frekuensi produksi dalam tahunan sehingga didapat siklus produksi) untuk produk tersebut. Data dikumpulkan dalam 3 tahun kebelakang. Nilai yang ditentukan adalah bila rasio bernilai $>1$ dan memiliki frekuensi produksi tahunan yang cukup sering, maka masuk ke dalam kategori make to stock. Bila nilai rasio dibawah 1 masuk ke dalam kategori finish good to order atau masuk ke dalam kategori make to order, pertimbangan ini berdasarkan pada sifat finish good itu sendiri (dilihat dari lamanya waktu expired, bila semakin singkat maka semakin condong ke dalam make to stock). 
Tabel 3. Capaian Inventory PT. HI tahun 2013 2016

\begin{tabular}{cccc}
\hline Tahun & & Target & Actual \\
\hline 2013 & 15 & KUSD & 14.8 KUSD \\
\hline 2014 & 13 & KUSD & 13.5 KUSD \\
\hline 2015 & 12 & KUSD & 13.1 KUSD \\
\hline 2016 & 11.5 KUSD & \\
\hline
\end{tabular}

Perhitungan data untuk penentuan rasio perbandingan production planning dan pending order dapat dilihat pada tabel 2.

Setelah didapatkan strategi produk, maka berikutnya adalah menentukan produksi bulanan untuk 2016 yang sudah disesuaikan dengan kapasitas produksi. Setelah didapatkan rencana produksi tahunan dengan mempertimbangkan strategi yang telah ditetapkan maka perusahaan dapat melihat gambaran nilai inventory. Untuk tahun 2014 dan 2015 perusahaan tidak dapat mencapai target inventory. Berikut terlampir nilai inventory akhir tahun untuk periode 2013 sampai 2015.

Setelah didapat list produk yang akan diproduksi per bulan, maka langkah selanjutnya adalah menghitung raw material yang dibutuhkan, kemudian melakukan pemesanan material dan menentukan kedatangan material

(MRP breakdown). Perhitungan ini memudahkan dalam menghitung inventory projection sampai pada akhir tahun 2016. Setelah dilakukan perhitungan inventory projecton, maka untuk periode tahun 2016 didapatkan projection nilai inventory per bulan dapat terlihat pada tabel berikut :

Tabel 2. Penentuan Strategi Produk

\begin{tabular}{|c|c|c|c|c|c|c|c|c|c|c|}
\hline \multirow{2}{*}{ Row Labels } & Demand & \multicolumn{2}{|r|}{ Ratio } & Demand & \multicolumn{2}{|r|}{ Ratio } & Demand & \multicolumn{2}{|r|}{ Ratio } & \multirow{2}{*}{ STRATEC' } \\
\hline & $\nabla 2016 \quad \nabla$ & & 2016 & $2015 \quad \nabla$ & & 2015 & $2014 \quad \nabla$ & & 2014 & \\
\hline TERASIL BLACK P-R LIQ 40\% & \begin{tabular}{l|l|} 
& 13,680 \\
\end{tabular} & 20,000 & 0.68 & 60,000 & 55,000 & \begin{tabular}{ll|}
0 & 1.09 \\
\end{tabular} & 30,000 & 30,000 & 1.00 & MTO \\
\hline TERASIL BLACK WW-KSN & 142,000 & 144,000 & 0.99 & 52,890 & 92,000 & 0.57 & 54,352 & 64,000 & 0.85 & MTS \\
\hline TERASIL BLUE BGE-01 200\% & 277,500 & 230,000 & 1.21 & 255,800 & 260,000 & 0.98 & 156,437 & 190,000 & 0.82 & MTS \\
\hline TERASIL BLUE LF & 11,400 & 12,000 & 0.95 & 57,200 & 44,000 & 1.30 & 6,533 & 8,000 & 0.82 & FTO \\
\hline TERASIL BLUE P-BGE LIQ & 92,000 & 92,000 & 1.00 & 56,000 & 56,000 & 1.00 & 34,256 & 20,000 & 1.71 & MTO \\
\hline TERASIL BLUE TC & 40,764 & 40,000 & 1.02 & 38,940 & 42,000 & 0.93 & 45,654 & 42,000 & 1.09 & FTO \\
\hline TERASIL BLUE W-BLS & 75,600 & 80,000 & 0.95 & 24,900 & 27,000 & 0.92 & 87,653 & 70,000 & 1.25 & FTO \\
\hline TERASIL BLUE WW-2GS & 51,600 & 56,000 & 0.92 & 50,700 & 60,000 & 0.85 & 54,443 & 50,000 & 1.09 & FTO \\
\hline TERASIL BROWN 2RFL 200\% & 85,798 & 84,000 & 1.02 & 86,001 & 70,000 & 1.23 & 64,543 & 70,000 & 0.92 & FTO \\
\hline TERASIL FIRE RED WW-GS & 20,100 & 20,000 & 1.01 & 67,716 & 60,000 & 1.13 & 69,834 & 100,000 & 0.70 & FTO \\
\hline TERASIL NAWWW-GSN & 98,730 & 96,000 & 1.03 & 69,312 & 72,000 & 0.96 & 89,823 & 40,000 & 2.25 & FTO \\
\hline TERASIL RED W-4BS & 73,400 & 80,000 & 0.92 & 85,800 & 90,000 & 0.95 & 76,529 & 90,000 & 0.85 & FTO \\
\hline TERASIL RED W-EL & 55,400 & 56,000 & 0.99 & 36,000 & 36,000 & 1.00 & 24,568 & 24,000 & 1.02 & FTO \\
\hline TERASIL RED WW-3BS & 93,500 & 90,000 & 1.04 & 36,000 & 36,000 & 1.00 & 76,283 & 90,000 & 0.85 & FTO \\
\hline TERASIL RED WW-BFS-01 200\% & 85,600 & 90,000 & 0.95 & 99,740 & 95,000 & 1.05 & 68,234 & 80,000 & 0.85 & FTO \\
\hline TERASIL RED WW-CBS & 134,700 & 130,000 & 1.04 & 160,500 & 110,000 & 1.46 & 78,316 & 40,000 & 1.96 & MTS \\
\hline TERASIL RED WW-FS & 72,655 & 60,000 & 1.21 & 14,400 & 10,000 & 1.44 & 29,987 & 45,000 & 0.67 & FTO \\
\hline TERASIL ROYAL BLUE WW & 68,700 & 70,000 & 0.98 & 78,564 & 80,000 & 0.98 & 8,963 & 8,000 & 1.12 & FTO \\
\hline TERASIL VIOLET WW-2RS & 39,900 & 38,000 & 1.05 & 5,472 & 5,000 & 1.09 & 6,734 & 8,000 & 0.84 & FTO \\
\hline TERATOP BLACK HL-ECO & 300 & 300 & 1.00 & 600 & 600 & 1.00 & 8,734 & 5,600 & 1.56 & MTO \\
\hline TERATOP BLACK HL-BL & 2,700 & 3,000 & 0.90 & 65,184 & 72,000 & 0.91 & 2,346 & 4,000 & 0.59 & FTO \\
\hline TERATOP BLACK HL-NF-01 & 127,900 & 126,000 & 1.02 & 52,700 & 70,000 & 0.75 & 187,643 & 189,000 & 0.99 & FTO \\
\hline TERATOP BLACK KTMS 133\% & 54,756 & 50,000 & 1.10 & 36,400 & 40,000 & 0.91 & 78,634 & 70,000 & 1.12 & FTO \\
\hline TERATOP BLACK LF-01 & 142,289 & 98,000 & 1.45 & 207,100 & 213,000 & 0.97 & 100,923 & 176,000 & 0.57 & FTO \\
\hline TERATOP BLUE BGE & 86,700 & 90,000 & 0.96 & 91,704 & 90,000 & 1.02 & 12,321 & 13,000 & 0.95 & FTO \\
\hline TERATOP BLUE HL-B 150\% & 92,400 & 75,000 & 1.23 & 62,200 & 65,000 & 0.96 & 98,735 & 48,000 & 2.06 & FTO \\
\hline TERATOP GREYHL & 5,600 & 6,000 & 0.93 & 6,516 & 6,000 & 1.09 & 9,823 & 8,000 & 1.23 & FTO \\
\hline TERATOP NAVYHL-N & 20,400 & 20,000 & 1.02 & 18,600 & 15,000 & 1.24 & 87,539 & 71,000 & 1.23 & MTS \\
\hline TERATOP YELLOW GWL-01 & 70,600 & 77,000 & 0.92 & 31,200 & 35,000 & 0.89 & 54,763 & 42,000 & 1.30 & FTO \\
\hline TERATOP YELLOW HL-G-01 150\% & 60,300 & 57,000 & 1.06 & 39,600 & 38,000 & 1.04 & 68,763 & 28,500 & 2.41 & MTS \\
\hline TERATOP YELLOW NFG & 3,300 & 4,000 & 0.83 & 22,512 & 20,000 & 1.13 & 48,763 & 56,000 & 0.87 & FT0 \\
\hline
\end{tabular}




\begin{tabular}{lcc}
\hline \multicolumn{1}{c}{ Bulan } & Nilai (Juta USD) & $\begin{array}{c}\text { DIO } \\
\text { (hari) }\end{array}$ \\
\hline January & 13.254 & 110 \\
\hline Febuary & 13.364 & 90 \\
\hline March & 13.039 & 121 \\
\hline April & 12.169 & 71 \\
\hline May & 13.568 & 81 \\
\hline June & 12.660 & 75 \\
\hline July & 12.263 & \\
\hline August & 13.115 & \\
\hline September & 12.189 & \\
\hline October & 12.008 & \\
\hline November & 11.856 & \\
\hline December & 11.325 & \\
\hline
\end{tabular}

Tabel 4. Nilai Inventory PT. HI Tahun 2016

Dari data di atas terlihat bahwa nilai inventory menurun secara stabil per bulan dan mencapai angka 11.3 juta USD ada akhir tahun. Hal ini menyatakan bahwa target untuk tahun 2016 tercapai dengan nilaitarget sebesar 11.5 juta USD. Kemudian nilai DIO menurun dari 110 menjadi 75 hari per bulan Juni 2016. Maka penentuan strategi produk sangat berpengaruh teradap penurunnan nilai inventory.

\section{Kesimpulan}

Dari pembahasan di atas dapat diketahui bahwa penentuan identitas strategi produk memiliki kontribusi yang cukup signifikan dalam upaya penurunan inventory. Banyak cara lain yang dapat dilakukan untuk penurunan inventory salah satunya dengan penerapan lean dan JIT, namun bila penerapan JIT dirasa sulit karena kondisi memiliki variable yang terlalu banyak, maka cara ini pun dapat digunakan.

Dengan menerapkan penentuan strategi produk, PT HI dapat mencapai target untuk inventory pada tahun 2016. Yaitu dengan nilai 11.3 juta dolar dari target 11.5 juta dolar dengan nilai DIO 75 hari per bulan Juni 2016.

Selanjutnya yang perlu diperhatikan oleh PT. HI adalah mengontrol raw material yang memiliki nilai yang cukup besar atau yang berpotensi mengganggu inventory. Penentuan material ini dapat dilaukan dengan sistem pareto.

\section{Daftar Pustaka}

Assauri, Sofjan, Manajemen Produksi dan Operasi Edisi Revisi, Lembaga Penerbit FE-UI, Jakarta, 2004

Alfares Hesham K (2007), "Inventory Model with Stock-Level Dependent Demand

Rate and Variable Holding Cost", International Journal of Production Economics,Vol. 108, pp. 259-265.
Barry, C. (2009). Take a financial view of inventory. Multichannel Merchant, 26(9), 55-n/a.

Davood Mohammaditabar, Seyed Hassan Ghodsypour and Chris O'Brien (2012),"Inventory Control System Design by Integrating Inventory Classification and Policy Selection", International Journal of Production Economics, Vol. 140, No. 2,pp. 655-659.

Dureno, D. J. (1995). Inventory management - A business issue. Hospital Materiel Management Quarterly, 17(2), 6.

Fildes, R., Hibon, M., Makridakis, S., \& Meade, N. (1998). Generalising about univariate forecasting methods: further empirical evidence. International Journal of Forecasting 14, 339-358.

Garai, Anny., \& Bon, Talib, Abdul. (2013).Just In Time Approach in Inventory Control. Universiti Tun Hussein Onn Malaysia.

Gupta, A., Garg, R. K., \& Tewari, P. C. (2012). Inventory selection criteria: A proposed classification. IUP Journal of Operations Management, 11(4), 41-52.

Harjanto, Eddy . (2008). Manajemen Operasi, Edisi ke-3, Grasindo, Jakarta.

Jamshidi, H., \& Jain, A. (2008). Multi-criteria ABC inventory classification: With exponential smoothing weights. Journal of Global Business Issues, 2(1), 61-67.

Kieso, Donald. E et al (2009) Akuntansi Intermediate, Edisi ke-12 Jilid 1, Erlangga, Jakarta

Kwak Choonjong, Choi Jin Sung, Kim Chang Ouk and Kwon Ick-Hyun (2009), "Situation Reactive Approach to Vendor Managed Inventory Problem", Expert Systems with Applications, Vol. 36, pp. 9039-9045. 
Martani, Dwi, dkk 2012, Akuntansi Keuangan Menengah Berbasis PSAK, Jilid 1, Salemba Empat, Jakarta

Mutakim, A. (2011). Pengukuran Kinerja Manajemen Rantai Pasokan dengan SCOR Model 9.0 (Studi Kasus di PT Indocement Tunggal Prakarsa Tbk). Jurnal Manajemen dan Organisasi, 2(3).

Nasution, A.H dan Prasetyawan, Y, (2008), Perencanaan dan Pengendalian Produksi, Edisi Pertama, Graha Ilmu, Yogyakarta
Puspika, J., \& Anita, D. (2013). Inventory Control dan Perencanaan Persediaan Bahan Baku Produksi Roti pada Pabrik Roti Bobo Pekanbaru. Jurnal Ekonomi, 21(03).

Pujawan, I , Nyoman. (2005). SupplyChain Management Penerbit Guna Widya. Surabaya Rangkuti, Freddy. 2000. Analisis SWOT Teknik Membedah Kasus Bisnis. Jakarta: Gramedia Pustaka.

Rangkuti, Freddy 2007, Manajemen Persediaan, Rajawali Pers, Jakarta.

Stanford, R. E., \& Martin, W. (2007). Towards a normative model for inventory cost management in a generalized $\mathrm{ABC}$ classification system. The Journal of the Operational Research Society, 58(7), 922-928. 